\title{
SISTEM PAKAR DETEKSI PENYAKIT GINJAL BERBASIS MOBILE ANDROID
}

\author{
Edwin Ariesto Umbu Malahina \\ Program Studi Teknik Diploma Tiga, STIKOM Uyelindo Kupang \\ Jln. Perintis Kemerdekaan I - Kayu Putih - Kupang - NTT - Indonesia \\ Email : edwinariesto@gmail.com
}

\begin{abstract}
Non-communicable diseases are diseases with the highest mortality where the mortality rate for this disease is $73 \%$. Kidney disease is one of the non-communicable diseases in which disorders that occur in the kidney, are in two organs shaped like red beans on both sides of the lower back, precisely below the rib cage. Kidney disease taken in this study were 7 diseases namely kidney stone, kidney failure, kidney cancer, acute kidney failure, kidney infection, kidney cysts and polycystic kidney disease. Where in detecting the symptoms of this disease, a truly expert system and expert data are needed, and the implementation of the system makes it easier to develop alternative services using an Android smartphone where users will choose symptoms to be detected early, of course only specifically for detecting kidney diseases. This system will be easy to apply and use because it has only one display. And this system has run well according to the rules of symptoms and diseases that are given or applied..
\end{abstract}

Keywords:: expert system, forward chaining, android, kidney illness, knowledge based system.

\section{PENDAHULUAN}

\subsection{Latar Belakang}

Sistem pakar atau expert system biasa disebut juga dengan knowledge based system yaitu suatu aplikasi computer yang ditujukan untuk membantu pengambilan keputusan atau pemecahan persoalan dalam bidang yang spesifik, yang menggunakan pengetahuan dan metode analisis dimana akan diidentifikasi terlebih dahulu pleh pakar yang sesuai bidang keahliannya [1].

Badan Penelitian dan Pengembangan Kesehatan telah menyelesaikan Riset Kesehatan Dasar (Riskesdas) 2018 yang dilakukan secara terintegrasi dengan Susenas Maret (Badan Pusat Statistik). Tahun 2018, Riskesdas menunjukan penyakit ginjal kronik naik dari $2 \%$ menjadi 3,8\%, [2], dari total populasi 258 juta penududuk Indonesia dimana $73 \%$ kematian di Indonesia disebebkan oleh Penyakit Tidak Menular (PTM), sedangkan jumlah kematian akibat PTM adalah 1.340 .000 jiwa, dan 27\% akan mengalami kematian dini akibat PTM [3].

Penanganan masalah diera teknologi saat inipun mulai berkembang seiring dengan kemajuan perangkat teknologi dan aplikasi salah satunya perangkat smartphone berbasis Android. Android sendiri dikenal sebagai teknologi open source yang mudah dikembangkan dengan berbagai fariasi jenis-jenis aplikasi salah satunya dibidang kesehatan tentunya dengan berbagai pengumpulan referensi dan ahli dibidangnya agar layanan yang dikembangkan sesuai aturan dan kaidah yang berlaku.
Pada permasalahan diatas maka akan dikembangkan salah satu teknik deteksi penyakit ginjal berbasis Android dengan penerapan kepada sistem pakar (expert system) dimana menggunakan metode forward chaining. Forward chaining merupakan pencocokan fakta atau pernyataan dimulai dari bagian sebelah kiri (IF dulu). Dengan kata lain, penelaran dimulai dari fakta terlebih dahulu untuk menguji kebenaran hipotesis [4]. Dari Teknik metode forward chaining ini maka dibuatkan layanan alternative yang dapat mendeteksi gejala-gejala penyakit ginjal yang diderita oleh pasien, adapun beberapa penyakit ginjal yang dapat di lansir dari situs Alodokter, dimana situs ini juga merupakan perusahaan kesehatan digital yang berdiri sejak 2014, yaitu beberapa jenis penyakit ginjal diantaranya adalah batu ginjal, gagal ginjal, kanker ginjal, gagal ginjal akut, infeksi ginjal, kista ginjal dan penyakit ginjal polikistik [5]

\subsection{Rumusan masalah}

Berdasarkan latar belakang yang telah dijabarkan, maka rumusan masalah dalam penelitian ini adalah bagaimana membangun aplikasi sistem pakar berbasis Android yang dapat mendeteksi jenis-jenis penyakit ginjal dengan mudah.

\subsection{Tujuan}

Tujuan dari penelitian ini adalah untuk membuat aplikasi sistem pakar berbasis Android agar dengan mudah diterapkan dan 
dimplementasikan kepada masyaraat serta sebagai edukasi untuk menangani penyakit-penyakit ginjal yang ada serta geja yang diderita, namun tidak serta merta mengganti tugas dokter, karena aplikasi inipun dikembangkan sebagai media bantu dan pengobatannya tetap wajib dilakukan atau ditangani oleh Dokter dibidangnya dan perawatan yang intensif.

\section{TINJAUAN PUSTAKA}

Berikut merupakan tiga (3) section penelitian yang serupa terkait judul penelitian yang diambil penulis dalam menunjang referensi yang ada, sebagai berikut :

\section{a. Sistem Pakar}

Sistem pakar atau expert system biasa disebut juga dengan knowledge based system yaitu suatu aplikasi komputer yang ditujukan untuk membantu pengambilan keputusan atau pemecahan persoalan dalam bidang yang spesifik, yang menggunakan pengetahuan dan metode analisis dimana akan diidentifikasi terlebih dahulu pleh pakar yang sesuai bidang keahliannya. [1]. System pakar dapat diilustrasikan melalui lonsep dasara system pakar berbasis pengetahuan (knowledge based expert system). User memberikan informasi atau fakta kepada system dan menerima respon berupa saran ahli (advice/expertise). Secara internal, system terdiri dari dua komponen utama yaitu basis pengetahuan (knowledge based), berisi pengetahuan yang akan digunakan oleh komponen lain yaitu mesin inferensi (inference engine) untuk menghasilkan kesimpulan sebagai respon terhadap kueri yang dilakukan oleh user. [4]

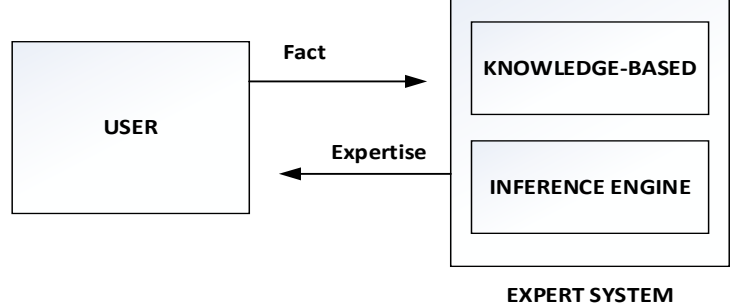

Gambar 1. Konsep dasar fungsi sistem pakar berbasis pengetahuan [4]

Pengetahuan yang dimiliki system pakar direpresentasikan dalam beberapa cara. Salah satu metode yang paling umu digunakan adalah tipe rules menggunakan format IF-THEN. Pengetahuan tidak tertulis yang dimiliki oleh seorang pakar harus diekstraksi melalui wawancara secara ekstensif oleh knowledge engineer. Proses pengembangan system pakar yang berhubungan dengan perolehan pengetahuan dari pakar maupun sumber lain dan kodingnya disebut sebagai knowledge engineering yang dilaksanakan oleh knowledge engineering.
Berikut tahapan pengembangan system pakar secara umum.

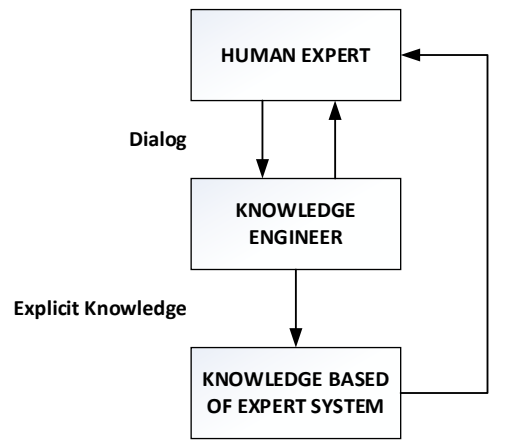

Gambar 2. Pengembangan sistem pakar [4]

\section{b. Forward Chaining}

Pelacakan kedepan (forward chaining) yang memulai dari sekumpulan data menuju kesimpulan, terlihat seperti gambar berikut ini :

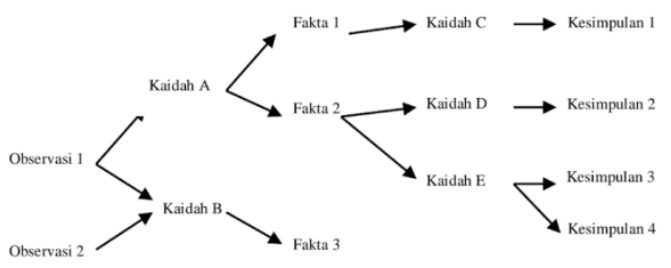

Gambar 3. Pelacakan kedepan (forward chaining)

[1]

Pada system pakar berbasis rule, domain pengetahuan direpresentasikan dalam sebuah kumpulan rule berbentuk IF-THEN, sedangkan data dipresentasikan dalam sebuah kumpulan fakta-fakta tentang kejadian saat ini.

Menurut Russel S dan Norving P (2003) dalam Hayadi [1] Metode forward chaining adalah metode pencarian atau Teknik pelacakan kedepan yang dimulai dengan informasi yang ada dan penggabungan rule untuk menghasilkan suatu kesimpulan atau tujuan.

Sedangkan menurut T.Sutejo, e.t (2010) dalam Hayadi [1] forward chaining adalah Teknik pencarian yang dimulai dengan fakta yang diketahui, kemudian mencocokan fakta-fakta tersebut dengan bagian IF dari rules IF_THEN. Bila ada fakta yang cocok dengan bagian IF maka rule tersebut dieksekusi. Bila sebuah rule dieksekusi, maka sebuah fakta baru (bagian THEN) ditambahkan kedlam database. Setiap rule hanya boleh dieksekusi sekali saja.

System pakar berbasis forward chaining berbasis aturan dapat dimodelkan sebagai beikut : 


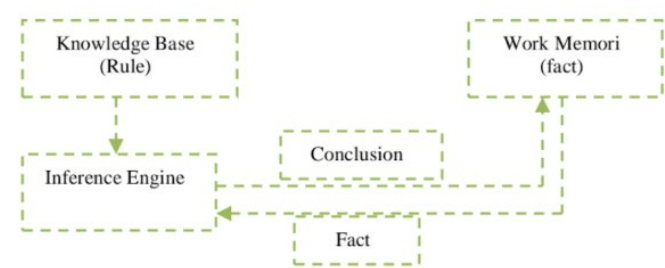

Gambar 4. Model berbasis aturan [1]

Operasi dari system forward chaining dimulai dengan memasukan sekumpulan fakta yang diketahui kedalam memory kerja (working memory), kemudian menrunkan fakta baru berdasarkan aturan yang premisnya cocok dengan fakta yang diketahui. Operasi tersebut dapat digambarkan sebagai berikut:

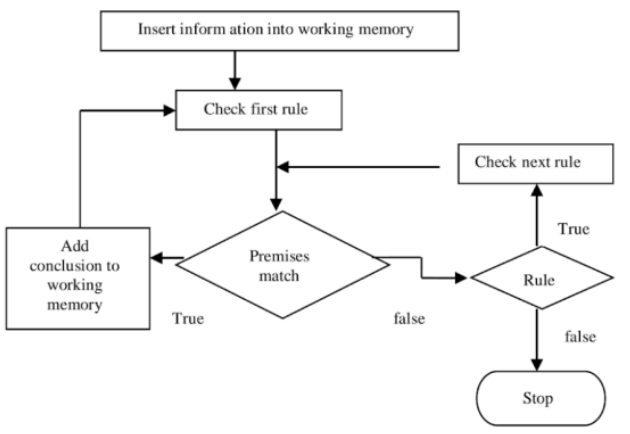

Gambar 5. Operasi system forward chaining [1]

Forward chaining juga memiliki aturan-aturan rules yang dapat ditunjukan melalui table berikut [4].

Table 1. Aturan forward chaining

\begin{tabular}{|l|l|}
\hline & \\
\hline R-1 & IF A \& B THEN C \\
\hline R-2 & IF C THEN D \\
\hline R-3 & IF A \& E THEN F \\
\hline R-4 & IF A THEN G \\
\hline R-5 & IF F \& G THEN D \\
\hline R-6 & IF G \& E THEN H \\
\hline R-7 & IF C \& H THEN I \\
\hline R-8 & IF I \& A THEN J \\
\hline R-9 & IF G THEN J \\
\hline R-10 & IF J THEN K \\
\hline
\end{tabular}

\section{c. Penyakit Ginjal}

Gagal ginjal adalah hilangnya fungsi ginjal. Apabila hanya $10 \%$ dari ginjal yang berfungsi, pasien dikatakan sudah sampai pada penyakit ginjal end-stage enal sisease (ESRD) atau penyakit ginjal tahap akhir. Gagal ginjal dapat juga kronik, yaitu terjadi perlahan dan berkembang perlahan, mungkindalam beberapa tahun. [6].

Penyakit ginjal juga adalah gangguan yang terjadi pada organ ginjal, yaitu dua buah organ berbentuk seperti kacang merah yang berada di kedua sisi tubuh bagian punggung bawah, tepatnya di bawah tulang rusuk.
Gangguan pada ginjal akan memengaruhi kinerja tubuh dalam mencuci darah, yaitu menyaring limbah tubuh dan cairan berlebih yang akan menjadi urine. Secara lebih spesifik, ginjal memiliki beberapa fungsi penting, antara lain:

1) Menyaring limbah tubuh (termasuk zat kimia, obat-obatan, dan makanan) dalam darah.

2) Menjaga keseimbangan kadar garam, mineral, cairan, dan asam darah dalam tubuh.

3) Menghasilkan eritropoetin, yaitu hormon yang berfungsi dalam pembentukan sel darah merah.

4) Menghasilkan renin, yaitu enzim yang membantu mengatur tekanan darah.

5) Menghasilkan senyawa aktif dari vitamin D untuk menjaga kesehatan tulang.

Ketika fungsi ginjal terganggu, zat sisa limbah tubuh dan cairan yang menumpuk di dalam tubuh akan menyebabkan gejala berupa pembengkakan pada pergelangan kaki, mual, muntah, lemas, dan sesak napas.

Penyakit ginjal dapat dipicu oleh kondisi lainnya, misalnya karena diabetes dan tekanan darah tinggi. Artinya, seseorang berisiko mengalami gangguan ginjal jika mengalami diabetes, tekanan darah tinggi, atau memiliki riwayat penyakit ginjal dalam keluarga.

\section{1) Jenis Penyakit Ginjal}

Penyakit ginjal terdiri dari beberapa jenis, antara lain:

a) Infeksi ginjal. Infeksi ginjal terjadi bila bakteri dari kandung kemih menyebar naik menuju ke salah satu atau kedua ginjal. Kondisi ini muncul akibat dari komplikasi infeksi saluran kemih.

b) Batu ginja. Garam dan mineral yang seharusnya disaring oleh ginjal tetapi malah mengeras dan tertimbun dalam ginjal sehingga terbentuk batu ginjal. Hal ini biasanya terjadi karena urine yang terlalu pekat, sehingga garam dan mineral mengkristal.

c) Penyakit ginjal polikistik. Merupakan penyakit keturunan berupa munculnya kista (kantong berisi cairan) yang berkelompok di dalam ginjal. Penyakit ginjal polikistik tidak ganas, namun dapat mengakibatkan penurunan fungsi ginjal. Selain terjadi di ginjal, kista pada ginjal polikistik juga bisa muncul di organ hati atau bagian lain dalam tubuh.

d) Gagal ginjal akut. Gagal ginjal akut adalah kondisi dimana ginjal tidak dapat berfungsi normal secara tiba-tiba. Jika tidak segera ditangani, kondisi ini bisa menyebabkan menumpuknya garam dan zat kimia lainnya di dalam tubuh dan memengaruhi fungsi organ tubuh lainnya. 
e) Penyakit ginjal kronis. Penyakit ginjal kronis atau gagal ginjal kronis yaitu penurunan fungsi ginjal yang menetap selama tiga bulan. Kondisi ini ditandai beberapa gejala, seperti sesak napas, mual, dan kelelahan. Namun kondisi ini tidak dirasakan oleh pasien bila masih stadium 1-3. Oleh karena itu, banyak orang tidak menyadari sedang mengalami kondisi ini hingga mencapai stadium lanjutan.

\section{2) Gejala Penyakit Ginjal}

Gejala penyakit ginjal tergantung dari jenis penyakitnya dan apakah penyakit tersebut mengakibatkan penurunan fungsi ginjal. Beberapa gejala penurunan fungsi ginjal dan gejala penyakit ginjal secara spesifik, antara lain:

a) Terjadi pembengkakan di pergelangan kaki dan sekitar mata.

b) Mual, muntah, kehilangan nafsu makan, dan penurunan berat badan.

c) Volume urine dan frekuensi buang air kecil berkurang.

d) Urine berbusa.

e) Merasa lelah dan sesak napas.

f) Kulit kering dan terasa gatal.

g) Terjadi kram otot, terutama di tungkai.

h) Susah tidur.

i) Tekanan darah tinggi.

j) Gangguan irama jantung.

k) Penurunan kesadaran.

1) Pada gagal ginjal akut dapat terlihat tanda dehidrasi.

m) Nyeri punggung bawah dan urine bercampur darah dapat terjadi pada penderita batu ginjal, penyakit ginjal polikistik, dan infeksi ginjal.

n) Pada penderita infeksi ginjal dan batu ginjal dapat timbul keluhan demam dan menggigil.

Anak-anak yang mengalami penyakit ginjal akan mudah mengantuk, tidak bertenaga, kehilangan nafsu makan, dan pertumbuhannya terhambat.

\section{3) Diagnosis Penyakit Ginjal}

Untuk mendeteksi adanya gangguan pada ginjal, dokter dapat melakukan berbagai pemeriksaan penunjang, yaitu:

a) Tes urine. Dilakukan untuk mengetahui kadar albumin dalam urine. Albumin merupakan salah satu jenis protein yang seharusnya terkandung di dalam darah. Jika ada albumin di dalam urine, artinya ginjal tidak berfungsi dengan baik dan secara tidak langsung kadar albumin dalam darah akan menurun. Analisis dan kultur kuman dari urin juga dapat dilakukan, untuk mengetahui adanya infeksi saluran kemih dan kuman penyebab infeksi tersebut.

b) Tes darah. Dilakukan untuk memeriksa kadar kreatinin, yaitu sebuah zat yang berasal dari jaringan otot. Jika mengalami kerusakan, ginjal tidak bisa membuang kreatinin dari dalam darah. Melalui tes darah, dokter juga akan mengetahui laju filtrasi glomerulus (GFR) pasien. Hasil pemeriksaan GFR akan menunjukkan fungsi dan kondisi ginjal pasien. Selain fungsi ginjal, tes darah dapat melihat $\mathrm{Hb}$ yang menurun karena produksi sel darah merah yang menurun.

c) Pemindaian. USG ginjal dan CT scan ginjal serta saluran kemih (urografi) dapat melihat kemungkinan batu ginjal dan penyakit ginjal polikistik.

\section{4) Pengobatan Penyakit Ginjal}

Sebelum menentukan jenis pengobatan untuk penyakit ginjal, dokter akan memastikan penyebabnya terlebih dulu. Beberapa jenis pengobatan yang bisa dilakukan untuk mengatasi penyakit ginjal adalah:

a) Obat-obatan. Dalam mengobati penyakit ginjal, dokter akan memberikan salah satu obat darah tinggi dari golongan ACE inhibitors (contohnya ramipril, captopril) atau ARBs (contoh valsartan, irbesartan). Selain mengontrol tekanan darah, kelompok obat ini juga bisa mengurangi kadar protein di dalam urine. Hormon erythropoietin (EPO) juga dapat diberikan pada penderita penurunan fungsi ginjal dengan anemia. Untuk infeksi ginjal dokter akan memberikan antibiotik selama satu sampai dua minggu.

b) Prosedur terapi batu ginjal. Batu ginjal yang kecil dan dengan gejala yang ringan tidak perlu tindakan khusus untuk mengatasinya. Pasien akan dianjurkan untuk minum 2 sampai 3 L per hari untuk membilas saluran kemih, diberikan obat penghilang rasa sakit seperti paracetamol atau ibuprofen, serta diberikan obat untuk melemaskan otot saluran kemih (alpha blocker) sehingga batu dapat keluar dengan cepat dan tanpa nyeri. Bila batu cukup besar dan dianggap tidak dapat keluar sendiri, dilakukan beberapa prosedur untuk mengeluarkan batu dari ginjal, yaitu:

i. Extracorporeal shock wave lithotripsy (ESWL). Batu dihancurkan menjadi 
ukuran yang lebih kecil sehingga dapat dibuang bersama urine dengan menggunakan gelombang suara yang menghasilkan getaran dari mesin ESWL.

ii. Ureteroscopic Lithotripsy (URS). Melalui metode URS akan dimasukkan selang yang dilengkapi dengan kamera ke dalam saluran kemih melalui lubang tempat urine keluar. Kemudian, batu akan dihancurkan dengan alat khusus sehingga menjadi ukuran yang lebih kecil, agar dapat dikeluarkan lewat saluran kemih.

iii. Percutaneous Nephrolithotomy (PCNL). PCNL dilakukan dengan mengambil batu dengan alat khusus yang dimasukkan melalui punggung untuk mencapai ginjal. Tindakan ini membutuhkan pembiusan (anestesi) umum.

c) Diet. Ginjal berfungsi untuk menyaring zat limbah tubuh, beberapa mineral dan cairan. Bila terdapat penurunan fungsi ginjal, sulit bagi ginjal untuk membuang zat-zat limbah tersebut..

d) Terapi pengganti ginjal. Jika ginjal sudah tidak berfungsi sebagaimana mestinya, terdapat tiga cara untuk menggantikan tugas ginjal, yaitu:

i. Cuci darah atau hemodialisis. Menggunakan mesin yang dihubungkan dengan pembuluh darah untuk menyaring dan membuang zat yang tidak diperlukan oleh tubuh di dalam darah..

ii. Continuous ambulatory peritoneal dialysis (CAPD). Berbeda dengan cuci darah, CAPD menggunakan selaput pada dinding perut dalam untuk mencuci darah.

iii. Cangkok ginjal atau transplantasi ginjal. Dilakukan dengan memindahkan satu ginjal dari donor yang cocok dan ditanamkan ke dalam tubuh penderita.

\section{5) Pencegahan Penyakit Ginjal}

Penyakit ginjal dapat ditimbulkan oleh diabetes atau hipertensi. Karena itu, salah satu cara yang bisa dilakukan untuk mencegah penyakit ginjal adalah dengan mengendalikan kedua penyakit tersebut. Sebab, jika kadar gula darah dan tekanan darah tidak terkontrol, maka lama-kelamaan ginjal akan rusak. Jika mengalami gejala-gejala penyakit ginjal atau memiliki riwayat penyakit ginjal dalam keluarga, pasien disarankan untuk menjalani pemeriksaan secara rutin. [7]

\section{d. Penelitian Terkait}

Terdapat beberapa penelitian terdahulu yang dijadikan sebagai referensi dalam pembuatan penelitian ini, diantaranya pada penelitian dalam bidang kebugaran oleh Moore dan Quintero 2018
[8] dengan judul Comparing forward and backward chaining in teaching Olympic weightlifting. Dimana dalam penelitian ini mengenai Teknik-teknik angkat besi yang tepat dan benar untuk peserta olympiade angkat berat, agar tidak mengalami resiko/cidera latihan angkat berat yang lebih tinggi.

Penerapan metode forward chaining juga dapat diimplementasikan pada diagnosa pada tananam /tumbuhan seperti pada penelitian yaitu : penerapan metode forward chaining pada aplikasi sistem pakar diagnosa penyakit pada tanaman bunga kamboja, dimana akan mengetahui penyakit apa saha yang menyerang dan begaimana menanggulanginya dengan menggunakan Android [9]. Mendeteksi juga pada hama dan penyakt padi [10]

Penrapan forward chaining berikut dalam penyakit yang diderita pada manusia seperti mendiagnosa penyakit diare dimana implemnatasi system menggunakan Android [11], untuk diagnosa penyakit Insomnia [12], sampai pada diagnosa penyakit pada anak [13] [14].

Dari hasil kajian literatur diatas dengan maka dapat disimpulkan dalam pengembangan layanan alternative aplikasi system pakar berbasis mobile Android akan sangat mudah di implementasikan dengan penerapan metode forward chaining dimana akan disesuaikan melalui rules dan referensi data penyakit ginjal serta gejala yang ada melalui pakar/ahli dibidang kedokteran.

\section{METODE PENELITIAN}

a. Metode Pengambilan Data

Dalam menunjang pencarian fakta dan pengumpulan data, yang dilakukan dalam penelitian ini adalah sebagai berikut:

1) Eksplorasi: Metode ini berupa pengumpulan data dari jurnal-jurnal, buku-buku maupun artikel-artikel di internet, kemudian data yang telah dikumpulkan dan dikaji serta dibuat intisari pembahasan. Salah satunya melalui situs Alodokter.

2) Pustaka: Penelitian dengan menggunakan dan memanfaatkan literatur-literatur yang dapat membantu penyelesaian masalah.

3) Observasi: Penelitian ini melakukan pengamatan secara langsung terhadap objek penelitian. Objek yang diamati adalah terkait dengan mendeteksi penyakit ginjal kepada masyarakat.

Menurut Sommerville, Waterfall Model merupakan salah satu model proses perangkat lunak yang mengambil kegiatan proses dasar seperti spesifikasi, pengembangan, validasi dan evolusi dengan mempresentasikannya sebagai fase-fase proses yangberbeda seperti analisis dan definisi persyaratan, perancangan perangkat lunak, implementasi dan pengujian unit, integrasi dan pengujian sistem, operasi dan pemeliharaan [15] 


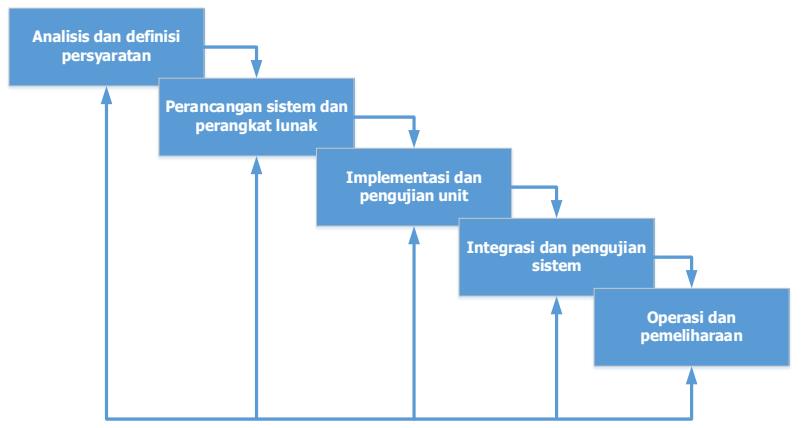

Gambar 6. Tahap survei menggunakan metode waterfall

\section{b. Bahan dan alat}

Adapun bahan dan alat yang digunakan dalam mengembangkan aplikasi system pakar penyakit ginjal adalah :

1) Bahan

Berupa literatur-literatur yang berkaitan dengan analisis dan perancangan sistem serta informasi yang berkaitan dengan pengembangan aplikasi, yaitu jurnal, buku dan inputan informasi yang dapat diberikan didalam layanan aplikasi.

2) Alat

Untuk menunjang pengembangan aplikasi, maka dibutuhkan perangkat keras dan perangkat lunak, antara lain:

a) Perangkat Lunak (software)

Adapun perangkat lunak yang dibutuhkan dalam pengembangan aplikasi adalah sebagai berikut:

i. Sistem operasi Windows 10 Home 64 bit.

ii. Microsoft Visio 2013 sebagai perancang alur sistem.

iii. Star UML sebagai perancang sistem.

iv. Android Studio 3.1

b) Perangkat Keras (hardware)

Perangkat keras yang digunakan untuk membangun aplikasi ini dengan menggunakan sebuah laptop, dengan spesifikasi sebagai berikut:
i. Laptop Asus ROG Strix Intel(R) Core(TM) i7-8750H CPU @ $2.20 \mathrm{GHz}$ $2.21 \mathrm{GHz}$
ii. Memory DDR4 16 GB.
iii. Harddisk 1TB
iv. Handphone Oppo F7, SO Android Oreo

\section{HASIL DAN PEMBAHASAN}

Aplikasi deteksi penyakit ginjal berbasis mobile android ini merupakan, sebuah layanan alternative untuk masyarakat agar bisa digunakan dengan lebih mudah dalam mendeteksi secara mandiri jika mengalami gangguan atau gejala-gejalan yang diderita didalam tubuh dengan lebih mudah dan praktis sehingga mendapatkan informasi yang akurat melalui penerapan metode forward chaining.

\section{a. Rule based penyakit ginjal}

Dari data yang didapatkan dari Alodokter, maka didapatkan 7 jenis penyakit ginjal diantaranya adalah batu ginjal, gagal ginjal, kanker ginjal, gagal ginjal akut, infeksi ginjal, kista ginjal dan penyakit ginjal polikistik [5] dan dimasukan kedalam table penyakit :

Table 2. Daftar Jenis Penyakit Ginjal

\begin{tabular}{|cl|}
\hline $\begin{array}{c}\text { Kode } \\
\text { Penyakit }\end{array}$ & \multicolumn{1}{c|}{ Penyakit } \\
P1 & Batu Ginjal \\
P2 & Gagal Ginjal Kronis \\
P3 & Kanker Ginjal \\
P4 & Gagal Ginjal Akut \\
P5 & Infeksi Ginjal \\
P6 & Kista Ginjal \\
P7 & Penyakit Ginjal Polikistik \\
\hline
\end{tabular}

Table 3. Daftar Gejala Penyakit Ginjal

\begin{tabular}{|c|c|}
\hline $\begin{array}{l}\text { Kode } \\
\text { Gejala }\end{array}$ & Gejala \\
\hline G1 & Sering buang air kecil \\
\hline G2 & Sakit saat buang air kecil \\
\hline G3 & Jumlah urine yang keluar sedikit \\
\hline G4 & Kemunculan darah di urine \\
\hline G5 & Pembengkakan pada tungkai \\
\hline G6 & $\begin{array}{l}\text { Tekanan darah tinggi (hipertensi) yang } \\
\text { tidak terkendali }\end{array}$ \\
\hline G7 & Demam dan menggigil \\
\hline G8 & Keluar keringat pada malam hari \\
\hline G9 & Kekurangan darah (anemia) \\
\hline G10 & Penurunan berat badan \\
\hline G11 & $\begin{array}{l}\text { Nyeri dan bengkak disekitar punggung } \\
\text { bawah dan pinggang }\end{array}$ \\
\hline G12 & Batuk darah \\
\hline G13 & Nyeri tulang \\
\hline G14 & $\begin{array}{l}\text { Pembengkakan pembuluh darah di } \\
\text { sekitar testis (terjadi pada pria). }\end{array}$ \\
\hline G15 & Kelenjar di bagian leher membengkak. \\
\hline G16 & Mual dan muntah. \\
\hline G17 & Nafsu makan berkurang. \\
\hline G18 & Bau napas menjadi tidak sedap. \\
\hline G19 & Sesak. \\
\hline G20 & Mudah lelah. \\
\hline G21 & $\begin{array}{l}\text { Penumpukan cairan dalam tubuh } \\
\text { (edema), yang dapat menyebabkan } \\
\text { pembengkakan pada tungkai atau kaki. }\end{array}$ \\
\hline G22 & Penurunan kesadaran. \\
\hline G23 & Dehidrasi. \\
\hline G24 & Kejang. \\
\hline G25 & Tremor \\
\hline G26 & $\begin{array}{l}\text { Nyeri pada punggung, di bawah tulang } \\
\text { rusuk (flank pain). }\end{array}$ \\
\hline G27 & Bau urine yang tidak seperti biasanya. \\
\hline G28 & $\begin{array}{l}\text { Rasa sakit dan tidak nyaman di sekitar } \\
\text { perut samping atau punggung. }\end{array}$ \\
\hline G29 & Diare. \\
\hline
\end{tabular}




\begin{tabular}{ll} 
G30 & $\begin{array}{l}\text { Darah dalam urine atau urine berwarna } \\
\text { gelap. }\end{array}$ \\
G31 & $\begin{array}{l}\text { Fungsi ginjal yang menurun (jarang } \\
\text { sekali terjadi). }\end{array}$ \\
G32 & Terbentuknya batu ginjal. \\
G33 & Kulit menjadi mudah memar. \\
G34 & Membesarnya ukuran perut. \\
G35 & Warna kulit menjadi pucat. \\
G36 & Sakit kepala. \\
G37 & Nyeri pada persendian. \\
G38 & Gagal ginjal. \\
G39 & Ketidaknormalan pada kuku. \\
G40 & Infeksi saluran kemih atau ginjal. \\
\hline
\end{tabular}

Berikut langkah-langkah penerpan deteksi penyakit ginjal menggunakan metode forward chaining, dimana bagian premis jika terpenuhi (IF) maka bagian konklusi (THEN) akan bernilai benar.

Table 4. Aturan diagnosa Penyakit Ginjal

\begin{tabular}{|clc|}
\hline Rule & \multicolumn{1}{c|}{ IF } & THEN \\
$\mathbf{1}$ & GI AND G2 AND G3 & P1 \\
$\mathbf{2}$ & G4 AND G5 AND G6 & P2 \\
$\mathbf{3}$ & G7 AND G8 AND G9 AND G6 & P3 \\
& AND G10 AND G11 AND G4 & \\
& AND G12 AND G13 AND G14 & \\
& AND G15 & \\
$\mathbf{4}$ & G3 AND G16 AND G17 AND & P4 \\
& G18 AND G19 AND G6 AND & \\
& G20 AND G21 AND G22 AND & \\
& G23 AND G24 AND G25 AND & \\
$\mathbf{5}$ & G26 G4 AND G27 AND G28 AND & P5 \\
& G7 AND G19 AND G24 AND & \\
$\mathbf{6}$ & G29 AND G19 \\
& G7 AND G30 AND G1 AND & P6 \\
G30 AND G31 AND G6 & \\
G32 AND G33 AND G34 AND & P7 \\
& G4 AND G35 AND G36 AND & \\
G24 AND G33 AND G1 AND & \\
& G37 AND G38 AND G39 AND & \\
G40 &
\end{tabular}

\section{b. Perancangan arsitektur sistem}

Arsitektur proses melakukan deteksi penyakit ginjal menggunakan smartphone Android:

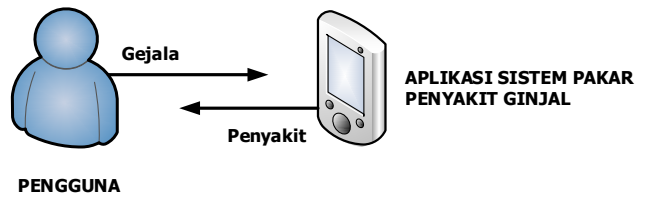

Gambar 7. Arsitektur sistem

\section{c. Rancangan use case diagarm}

Proses use case diagram aplikasi ini akan menggambarkan hak akses menu sistem yang akan digunakan oleh pengguna dalam menelusuri gejala sampai melihat hasil nama penyakit.

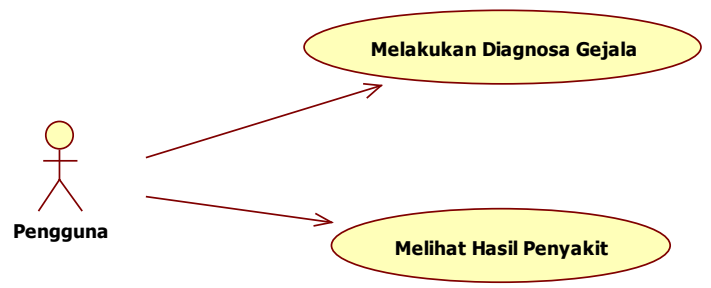

Gambar 8. Use case diagram aplikasi

Proses class diagram merupakan hubungan relasi antara user interface, control serta entity yang telah dibuat.

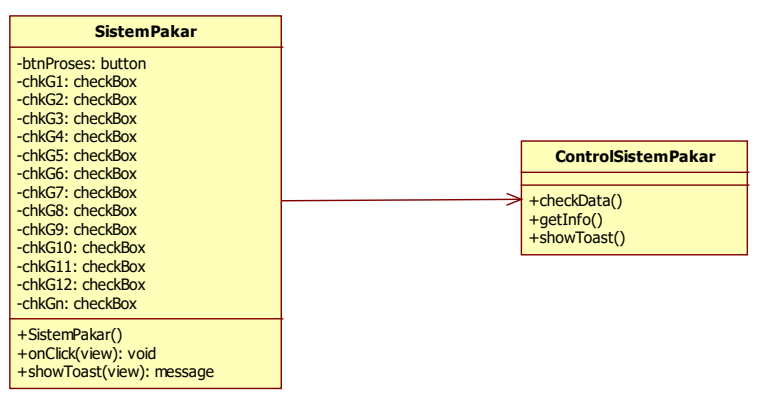

Gambar 9. Class diagram aplikasi

\section{d. Rancangan antarmuka aplikasi}

Pada tahap akhir ini akan dijelaskan user interface aplikasi yang dibangun dan dikelola oleh pengguna dan admin.

1) Tampilan antarmuka aplikasi

Berikut merupakan halaman gejala dan diagnose penyakit ginjal berbasis mobile android, dimana terdapat beberapa checkbox nama-nama gejala penyakit ginjal yang dapat di pilih oleh pengguna untuk mendiagnosa secara mandiri dari sakit yang diderita atau dirasakan oleh tubuh:

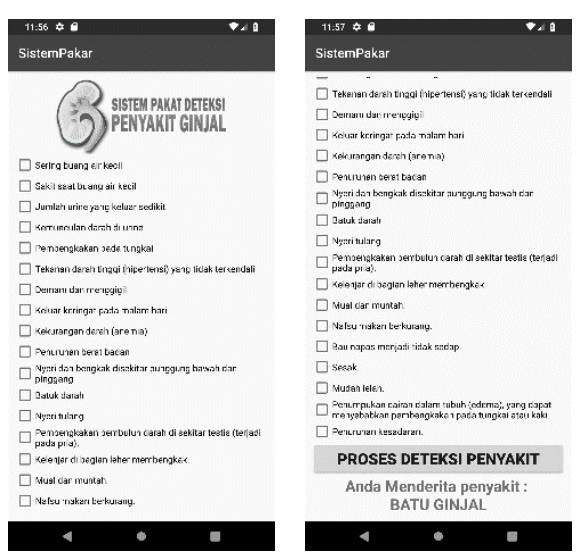

Gambar 7. Tampilan apliksi system pakar penyakit ginjal

Berdasarkan hasil uji fungsi dan rules dapat disimpulkan bahwa secara umum sistem ini sudah memenuhi tujuan utamanya yaitu terkait aplikasi deteksi penyakit ginjal berbasis mobile Android 
yang telah sesuai aturan gejalan dimana menghailkan jenis penyakit ginjal yang akan muncul sesuai gejala yang diderita ataupun tidak.

\section{KESIMPULAN}

Berdasarkan hasil penelitian dan pengembangan system yang telah dilakukan, penulis mengambil kesimpulan bahwa dengan menerapkan sistem aplikasi system pakar mendeteksi penyakit ginjal berbasis mobile android ini, pasien atau penderita dapat dengan mudah mengoperasikan atau mendiagnosa melalui layanan aplikasi yang dikembangkan, dengan mudah. Dan system telah berjalan dengan baik dan sesuai dengan rules yang didapatkan tentang penyakit ginjal.

Saran yang dapat penulis berikan adalah penelitian yang dilakukan masih ada beberapa kekurangan, sehingga penulis memberikan saran sebagai berikut:

a. Bagi peneliti yang ingin mengembangkan sistem ini dapat dipraktekkan ke sistem versi website atau platform mobile iOS.

b. Dapat menambahkan layanan konsultasi atau ruang tanya jawab agar dapat berinteraksi dengan pakar.

c. Memberikan solusi pengobatan jika terdeteksi penyakit yang diderita

\section{DAFTAR PUSTAKA}

[1] B. H. Hayadi, Sistem Pakar : Penyelesaian Kasus Menentukan Minat Baca Kecenderungan, dan Karakter Siswa dengan Metode Forward Chaining, Yogyakarta: Deepublish, 2018.

[2] D. "Potret Sehat Indonesia dari Riskesdas 2018," Kementerian Kesehatan Republik Indonesia, 2 November 2018. [Online]. Available:

http://www.depkes.go.id/article/view/181102 00003/potret-sehat-indonesia-dari-riskesdas2018.html. [Diakses 8 Juni 2019].

[3] N. F. Moelonek, “Air Bagi Kesehatan : Upaya Peningkatan Promotif Preventif Bagi Kesehatan Ginjal di Indonesia," Kementrian Kesehatan Republik Indonesia, 8 Maret 2018. [Online].

Available: https:/www.persi.or.id/images/2018/data/mat eri_menkes.pdf. [Diakses 8 Juni 2019].

[4] R. Rosnelly, Sistem Pakar : Konsep dan Teori, Yogyakarta: Andi Offset, 2012.

[5] Alodokter, "Daftar Penyakit," Alodokter, 6 Desember 2018. [Online]. Available: https://www.alodokter.com/penyakit-a-z\#. [Diakses 13 Juni 2019].

[6] M. Baradero, M. W. Dayrit dan Y. Siswadi, Klien Ganguan Ginjal : Seri Asuhan Keperawatan, Jakarta: Buku Kedokteran EGC, 2008.
[7] M. "Penyakit Ginjal," Alodokter, 20 Oktober 2017. [Online]. Available: https://www.alodokter.com/penyakit-ginjal. [Diakses 13 Juni 2019].

[8] J. W. Moore dan L. M. Quintero, “Comparing forward and backward chaining in teaching Olympic weightlifting," Journal of Applied Behavior Analysis, vol. LII, no. 6, pp. 50-59, 2018.

[9] A. M. R. Tanshidiq, A. D. Hartanto dan D. Prabowo, "PENERAPAN METODE FORWARD CHAINING PADA APLIKASI SISTEM PAKAR DIAGNOSA PENYAKIT PADA TANAMAN BUNGA KAMBOJA," Jurnal Ilmiah Data Manajemen dan Teknologi Informasi, vol. XVIII, no. 2, pp. 60-66, 2017.

[10] K. Aeni, "Penerapan Metode Forward Chaining Pada Sistem Pakar Untuk Diagnosa Hama Dan Penyakit Padi," Jurnal INTENSIF, vol. II, no. 1, pp. 79-86, 2018.

[11] J. Trianto, "PENERAPAN METODE FORWARD CHAINING UNTUK DIAGNOSA PENYAKIT DIARE PADA ANAK USIA 3-5 TAHUN BERBASIS MOBILE," JURNAL INFORMATIKA UNIVERSITAS PAMULANG, vol. III, no. 2, pp. 98-103, 2018.

[12] R. Amin dan P. Pitriani, "PENERAPAN METODE FORWARD CHAINING UNTUK DIAGNOSA PENYAKIT INSOMNIA," Jurnal PILAR Nusa Mandiri, vol. XIV, no. 1, pp. 97-102, 2018.

[13] C. R. Pasalli, V. C. Poekoel dan X. Najoan, "Sistem Pakar Diagnosa Penyakit Anak Menggunakan Metode Forward Chaining Berbasis Mobile," E-Journal Teknik Informatika, vol. VII, no. 1, 2016.

[14] B. F. Yanto, I. Werdiningsih dan E. Purwanti, "Aplikasi Sistem Pakar Diagnosa Penyakit Pada Anak Bawah Lima Tahun Menggunakan Metode Forward Chaining," Journal of Information Systems Engineering and Business Intelligence, vol. III, no. 1, pp. 6167, 2017.

[15] L. Sommerville, Software Engineering (Rekayasa Perangkat Lunak), Jakarta: Erlangga, 2011. 